\title{
PENYESUAIAN MUSIM TANAM, JENIS VARIETAS, DAN TEKNIK BUDIDAYA TANAMAN PADI TERKAIT MITIGASI EMISI METANA (Determination of Early Planting Season, Type Varieties, and Cultivation Techniques of Rice as Mitigation to Methane Emission)
}

\author{
Lilik Slamet Supriatin* \\ Pusat Sains dan Teknologi Atmosfer, LAPAN, Jl. dr. Djundjunan 133, Bandung 40173. \\ *Penulis korespondensi. Tel: 081394307769. Email: lilik_lapan@yahoo.com.
}

Diterima: 1 September 2016

Disetujui: 17 Desember 2016

\begin{abstract}
Abstrak
Emisi metana $\left(\mathrm{CH}_{4}\right)$ dari pertanian padi lahan sawah dapat dipengaruhi oleh faktor-faktor seperti cara pemberian air, pengolahan tanah, varietas padi, dan iklim. Pada penelitian ini dikaji tahap penentuan musim tanam, pemilihan varietas padi, dan tahap terakhir adalah teknik budidaya pertanian padi lahan sawah yang terkait mitigasi emisi $\mathrm{CH}_{4}$. Hasil kajian menunjukkan bahwa musim tanam padi pada musim kemarau menghasilkan emisi $\mathrm{CH}_{4}$ lebih kecil daripada di musim hujan dengan pengurangan emisi $\mathrm{CH}_{4}$ sebesar $18,13 \%$. Indonesia yang memiliki tiga tipe pola curah hujan tahunan (monsunal, equatorial, lokal) mengakibatkan periode musim tanam rendah emisi $\mathrm{CH}_{4}$ berbeda antara tipe curah hujan yang satu dengan lainnya. Varietas padi Way apo buru adalah varietas yang menghasilkan emisi $\mathrm{CH}_{4}$ terendah tetapi tetap optimum dalam produksi gabah sehingga dapat dipilih menjadi prioritas pertama untuk ditanam. Teknik budidaya pertanian padi lahan sawah yang menghasilkan rendah emisi $\mathrm{CH}_{4}$ dapat dilakukan dengan membuat genangan air yang dangkal saja, dengan cara pemberian air berselang, dan kombinasi antara pemeliharaan padi, ganggang, tanaman paku air, ikan air tawar, dan bakteri metanotrof dalam satu petak lahan sawah (mina padi plus). Pemberian air dengan cara berselang menurunkan emisi $\mathrm{CH}_{4}$ pada musim kemarau sebesar 59,36\% dan pada musim hujan sebesar $51,68 \%$ jika dibandingkan dengan pemberian air secara terus-menerus (kontinyu). Teknik budidaya mina padi plus mengurangi emisi $\mathrm{CH}_{4}$ sebesar $21,5 \mathrm{~kg} / \mathrm{ha} /$ musim tanam dan bakteri metanotrof mengurangi emisi $\mathrm{CH}_{4} \mathrm{ke}$ atmosfer sebesar 20-60 Tg. Sawah dapat dijadikan sebagai instalasi terbuka pengolahan udara berlimbah $\mathrm{CH}_{4}$.
\end{abstract}

Kata kunci: sawah, metana, mitigasi, teknik, budidaya, emisi, gas rumah kaca.

\begin{abstract}
Methane $\left(\mathrm{CH}_{4}\right)$ emissions from rice cultivation can be influenced by several factors i.e. the provision of water, soil cultivation, varieties of rice, and the climate. This study will examine the determination of the growing season, the selection of rice varieties and cultivation techniques of rice agriculture-related wetland mitigation of the $\mathrm{CH}_{4}$ emission. The results showed that the rice planting season in the dry season produces $\mathrm{CH}_{4}$ emissions is smaller than in the rainy season with $\mathrm{CH}_{4}$ emission reduction of $18.13 \%$. Indonesia, which has three types of annual rainfall patterns resulting in periods of low growing season $\mathrm{CH}_{4}$ emissions differ between types of rainfall each other. Way apo buru rice species are varieties that produce low emissions of $\mathrm{CH}_{4}$ but remains optimum in grain production. Cultivation techniques of rice farming rice fields that produce low emissions of $\mathrm{CH}_{4}$ can be done by creating a pool of shallow water only, by way of provision of water intermittent, and the combination of maintenance of rice, algae, plants salviniales, freshwater fish, and bacteria metanotrof in a wetland. The provision of water by intermittent lowering emissions of $\mathrm{CH}_{4}$ in the dry season by $59.36 \%$ and in the rainy season amounted to $51.68 \%$ when compared to the provision of water continuously (continuous). Mina padi plus cultivation techniques reduce $\mathrm{CH}_{4}$ emissions by $21.5 \mathrm{~kg} / \mathrm{ha} /$ planting and metanotrof bacteria can reduce $\mathrm{CH}_{4}$ emissions to the atmosphere by 20-60 Tg.
\end{abstract}

Keywords: paddy field, mitigation, methane, technique, cultivation, emission, greenhouse gas.

\section{PENDAHULUAN}

Secara tradisional penentuan musim tanam padi di lingkungan petani dahulu biasanya menggunakan kearifan lokal prakiraan musim tanam yang berkembang secara setempat, seperti Pranata Mangsa di Jawa, Palontara di Sulawesi Selatan, atau Waruga di Bali. Perkembangan ilmu pengetahuan dan teknologi benih serta agrokimia (pupuk dan insektisida) mengakibatkan penggunaan kearifan lokal jenis ini mulai bergeser dan ditinggalkan, walaupun masih ada saja petani yang menggunakan jenis kearifan lokal ini di beberapa daerah. Jika menggunakan pengetahuan agroklimatologi, awal musim tanam dapat ditentukan dengan memperhatikan pola curah hujan bulanan, persepuluh harian (dasarian) atau permingguan (Karim, 1985).

Pertanian padi sawah dihadapkan pada sebuah dilema, antara kepentingan ekonomi dan dampak ekologi (dampak lingkungan). Pada sisi ekonomi, pertanian padi sawah diharapkan mampu 
menghasilkan produksi padi yang maksimal setiap tahun dengan frekuensi tanam padi (musim tanam) yang diusahakan sampai 4 kali dalam setahun. Hal ini mengingat kebutuhan masyarakat Indonesia akan beras yang tinggi. Rata-rata konsumsi beras per kapita per tahun orang Indonesia adalah termasuk tertinggi di dunia. Kebutuhan per kapita beras pada tahun 2014 adalah $130 \mathrm{~kg}$ (BPS, 2014). Pada sisi ekologi dampak peningkatan emisi $\mathrm{CH}_{4}$ berupa pemanasan global dan perubahan iklim yang dihasilkan oleh pertanian padi sawah ke lingkungan harus mendapat perhatian.

Intergovernmental Panel On Climate Change (IPPC, 1995) menyatakan bahwa secara global besarnya emisi $\mathrm{CH}_{4}$ sumber alami berasal dari lahan basah $72 \%$, rayap $13 \%$, laut $6 \%$, dan lainnya 9\%. Sumber antropogenik $\mathrm{CH}_{4}$ terdiri dari pertanian padi sawah $16 \%$, peternakan hewan besar $23 \%$, gas alam 26\%, pembakaran biomassa $11 \%$, dan limbah padat dan cair 24\%. Sekitar $90 \% \mathrm{CH}_{4}$ yang dilepaskan dari lahan sawah ke atmosfer bersumber dari tanaman padi dan sisanya sebanyak $10 \%$ berasal dari gelembung air (ebullition). Ditambahkan oleh Dewan Nasional Perubahan Iklim (DNPI, 2010) sektor pertanian menduduki emisi gas rumah kaca $\left(\mathrm{CH}_{4}, \mathrm{CO}_{2}, \mathrm{~N}_{2} \mathrm{O}, \mathrm{H}_{2} \mathrm{O}\right)$ tertinggi ke tiga di Indonesia setelah emisi gas rumah kaca dari perubahan tata guna lahan di peringkat pertama dan pada peringkat ke dua adalah emisi gas rumah kaca dari lahan gambut.

Tanah sawah yang ditanami padi diperkirakan mengemisi sebesar 20 - 120 juta ton $\mathrm{CH}_{4}$ per tahun ke atmosfer. Emisi total tersebut berasal dari total luasan lahan dunia yang digunakan untuk budidaya padi sawah yang mencapai $1,45 \times 10^{6} \mathrm{~km}^{2}$ atau sekitar $10 \%$ dari total lahan pertanian dunia (Yagi dan Minami, 1990; Lelieveld dan Crutzen, 1993; Panjaitan dkk., 2015). Ditambahkan oleh Mosier dkk. (1994) yang menyatakan bahwa emisi $\mathrm{CH}_{4}$ berkontribusi sebesar $15 \%$ dari total efek rumah kaca yang dihasilkan oleh gas-gas rumah kaca.

Gas $\mathrm{CH}_{4}$ (metana) sebagai gas rumah kaca yang terdapat di atmosfer akan berperan penting pada pemanasan global setelah gas rumah kaca jenis $\mathrm{CO}_{2}$ (karbon dioksida) (Rahmansyah dan Sudiana, 2010). Kenaikan konsentrasi $\mathrm{CH}_{4}$ di atmosfer sebesar 1,3 ppmv akan mengakibatkan peningkatan suhu global sebesar $1,3{ }^{\circ} \mathrm{C}$ (Kiehl and Dickenson, 1987). Peningkatan emisi dan konsentrasi $\mathrm{CH}_{4}$ di atmosfer belakangan ini perlu diantisipasi mengingat potensi dan daya pemanasan global yang besar dari $\mathrm{CH}_{4}$. Bobot molekul (BM) $\mathrm{CH}_{4}$ yang besarnya hanya 16 (paling kecil dan ringan di antara bobot molekul gas rumah kaca lainnya) berpotensi melayang sampai jauh masuk ke stratosfer tempat lapisan ozon $\left(\mathrm{O}_{3}\right)$ berada dan akan merusak lapisan ozon tersebut (Biswas and
Biswas, 1979; Warneck, 1988). Peningkatan suhu bumi karena emisi dan konsentrasi $\mathrm{CH}_{4}$ disebabkan oleh dua hal, yaitu pertama efek gas rumah kaca dari $\mathrm{CH}_{4}$ sendiri dan ke dua dari $\mathrm{CH}_{4}$ yang masuk ke stratosfer akan merusak lapisan ozon sehingga radiasi ultra violet matahari akan masuk ke bumi dengan intensitas yang lebih tinggi.

Kepedulian dan kesadaran akan adanya isu lingkungan berupa pemanasan global dan perubahan iklim yang salah satunya disebabkan dan bersumber dari kegiatan budidaya padi sawah yang mengemisikan $\mathrm{CH}_{4}$ (metana) mengakibatkan penentuan musim tanam untuk saat ini seharusnya tidak saja memperhitungkan pola curah hujan, tetapi juga memperhatikan berapa besar emisi $\mathrm{CH}_{4}$ yang akan dihasilkan jika padi ditanam pada musim hujan atau di musim kemarau. Panjaitan dkk. (2015) menyatakan bahwa emisi $\mathrm{CH}_{4}$ dipengaruhi oleh pengelolaan air, pengolahan tanah, varietas padi, dan iklim.

Oleh karena itu masalah dari penelitian ini dapat dirumuskan yaitu belum terdapatnya kajian komprehensif dari tahap pertama yaitu waktu musim tanam, tahap ke dua pemilihan jenis varietas, dan tahap ke tiga teknik budidaya padi sawah yang berorientasi untuk mitigasi (pengurangan) emisi gas $\mathrm{CH}_{4}$. Jika setiap tahaptahap menanam padi sawah dari mulai penentuan awal musim tanam, dilanjutkan dengan pemilihan varietas padi serta teknik budidaya padi yang kesemuanya berorientasi pada emisi $\mathrm{CH}_{4}$ yang minim, maka emisi $\mathrm{CH}_{4}$ ke atmosfer dapat berkurang dan potensi pemanasan global serta perubahan iklim dapat dicegah dan diantisipasi. Tujuan penelitian ini adalah menganalisis dan memberikan informasi waktu musim tanam, jenis varietas padi yang ditanam, dan teknik budidaya tanaman padi yang minim menghasilkan emisi $\mathrm{CH}_{4}$.

\section{METODE PENELITIAN}

Pendekatan yang digunakan pada penelitian ini adalah pendekatan kuantitatif dengan metode penelitian adalah survey. Metode penelitian yang digunakan untuk menentukan musim tanam padi yang dapat meminimumkan emisi $\mathrm{CH}_{4}$ adalah tidak secara langsung melakukan percobaan (eksperimen) di lapangan, tetapi dengan studi literatur penelitian-penelitian sebelumnya dan menganalisis. Data fluks emisi $\mathrm{CH}_{4}$ yang dihasilkan pada berbagai musim tanam adalah data sekunder.

Metode analisis yang digunakan untuk memilih varietas padi yang minim emisi gas $\mathrm{CH}_{4}$ tetapi optimum pada produksi adalah dengan membuat rasio ekoefisiensi. Ekoefisiensi menurut Schmidheiny (1992) adalah suatu upaya untuk memproduksi barang dan jasa secara lebih 
bermanfaat, dan secara kontinyu berusaha mereduksi konsumsi sumber daya dan pencemaran. Pertanian padi sawah menghasilkan barang berupa beras sebagai makanan pokok masyarakat Indonesia dan dengan menanam varietas padi yang memperhatikan emisi $\mathrm{CH}_{4}$ berarti mereduksi pencemaran yang dihasilkan oleh pertanian padi sawah. Rasio antara emisi $\mathrm{CH}_{4}$ yang dihasilkan selama penanaman varietas padi tertentu terhadap produksi beras suatu varietas padi oleh penulis disebut dengan rasio ekoefisiensi. Formulasi untuk menentukan rasio ekoefisiensi (RE) tersaji pada persamaan 1 berikut.

$$
\mathrm{RE}=\frac{\text { Emisi Metana }\left(\frac{\mathrm{kg}}{\mathrm{ha}}\right)}{\text { Produksi Beras }\left(\frac{\mathrm{kg}}{\mathrm{ha}}\right)}
$$

Data yang digunakan untuk membuat rasio ekoefisiensi adalah emisi $\mathrm{CH}_{4}$ dan produksi berbagai varietas padi yang merupakan data sekunder. Tabel 1 menyajikan data emisi $\mathrm{CH}_{4}$ dan produksi gabah yang dihasilkan beberapa varietas padi.

Metode yang digunakan untuk menentukan teknik budidaya tanaman padi yang dapat meminimumkan emisi gas $\mathrm{CH}_{4}$ adalah dengan melakukan studi pustaka dan analisis. Data tentang teknik budidaya padi dan emisi $\mathrm{CH}_{4}$ adalah data sekunder. Berdasarkan studi pustaka tersebut dan analisis akan ditentukan teknik budidaya tanaman padi yang dapat meminimumkan emisi $\mathrm{CH}_{4}$.

\section{HASIL DAN PEMBAHASAN}

Pada pertanian padi lahan sawah, gas $\mathrm{CH}_{4}$ dihasilkan dari pembusukan bahan organik yang terdapat pada lahan sawah yang tergenang (kondisi anaerob). Bahan organik ini dapat berasal dari eksudat akar dan sisa tanaman padi yang menjadi substrat bagi bakteri metanogen untuk menghasilkan $\mathrm{CH}_{4}$. Metana yang telah dihasilkan oleh bakteri metanogen akan disalurkan melalui pembuluh aerenkim tanaman padi untuk dilepas/diemisikan ke atmosfer.

Banyak sudah penelitian tentang pengaruh musim tanam padi pada emisi $\mathrm{CH}_{4}$ yang dihasilkan. Beberapa diantaranya oleh Suharsih dkk (2000) dan Panjaitan dkk (2015). Tabel 2 menyajikan fluks emisi $\mathrm{CH}_{4}$ yang dihasilkan oleh beberapa perlakuan dan ulangan dari penelitian Suharsih (1999) dan Panjaitan dkk (2015).

Berdasarkan Tabel 2 dapat diketahui secara rata-rata emisi $\mathrm{CH}_{4}$ pada musim hujan lebih besar daripada musim kemarau untuk ke dua penelitian. Pada penelitian Suharsih dkk (1999), emisi $\mathrm{CH}_{4}$ rata-rata pada musim kemarau adalah 66,872 $\mathrm{kg} / \mathrm{ha} / \mathrm{musim}$ tanam lebih kecil jika dibandingkan pada musim hujan $(79,002 \mathrm{~kg} / \mathrm{ha} /$ musim tanam). Jika dipersentasekan, maka penanaman padi atau musim tanam padi yang dilakukan pada musim hujan akan menghasilkan emisi $\mathrm{CH}_{4}$ yang lebih tinggi sebesar $18,13 \%$ jika dibandingkan padi ditanam pada musim kemarau.

Demikian juga dengan penelitian yang dilakukan oleh Panjaitan dkk (2015), emisi $\mathrm{CH}_{4}$ rata-rata pada musim kemarau sebesar 0,467 $\mathrm{mg} / \mathrm{m}^{2} /$ menit yang lebih kecil daripada musim tanam yang dilakukan pada musim hujan $(0,687$ $\mathrm{mg} / \mathrm{m}^{2} / \mathrm{menit}$ ). Penanaman padi pada musim hujan akan menghasilkan emisi $\mathrm{CH}_{4}$ yang lebih tinggi sebesar $47,10 \%$ daripada padi ditanam pada musim kemarau. Perbedaan nilai persentase yang dihasil kan oleh ke dua penelitian dapat disebabkan karena pengaruh dari $\mathrm{pH}$ air hujan, jenis varietas padi yang ditanam, jenis tanah, dan teknik budidaya yang digunakan, tetapi pada umumnya musim tanam padi yang dilakukan pada musim hujan selalu menghasilkan emisi $\mathrm{CH}_{4}$ lebih tinggi daripada melakukan tanam padi pada musim kemarau.

Tabel 1. Emisi $\mathrm{CH}_{4}$ dan produksi beberapa varietas padi.

\begin{tabular}{lcc}
\hline Varietas Padi & $\begin{array}{c}\text { Emisi CH} \\
(\mathrm{kg} / \mathrm{ha})\end{array}$ & $\begin{array}{c}\text { Produksi gabah } \\
(\mathrm{kg} / \mathrm{ha})\end{array}$ \\
\hline Banyuasin & 171 & 2670 \\
Batang Anai & 196 & 4500 \\
Batanghari & 100 & 1560 \\
Cisadane & 218 & 6400 \\
Dodokan & 74 & 3300 \\
IR 36 & 112 & 4900 \\
IR 64 & 176 & 6700 \\
Mamberamo & 173 & 7400 \\
Maros & 117 & 4300 \\
Muncul & 127 & 4600 \\
Punggur & 182 & 4050 \\
Tenggulang & 121 & 3220 \\
Way Apo Buru & 154 & 7400 \\
\hline Sumber: Setyanto $\&$ Suharsh
\end{tabular}

Sumber: Setyanto \& Suharsih (2005), Susilawati dkk. (2009).

Tabel 2. Fluks emisi $\mathrm{CH}_{4}$ pada kondisi dua musim berbeda.

\begin{tabular}{ccccc}
\hline Ulangan/ & \multicolumn{2}{c}{ Emisi $\mathrm{CH}_{4}(\mathrm{~kg} / \mathrm{ha} / \mathrm{musim})^{1}$} & \multicolumn{2}{c}{ Emisi $\mathrm{CH}_{4}\left(\mathrm{mg} / \mathrm{m}^{2} / \mathrm{menit}^{2}\right.$} \\
\cline { 2 - 5 } Perlakuan & Musim kemarau & Musim hujan & Musim kemarau & Musim hujan \\
\hline 1 & 99,83 & 145,94 & 0,516 & 0,643 \\
2 & 34,54 & 46,19 & 0,454 & 0,659 \\
3 & 31,28 & 45,92 & 0,466 & 0,663 \\
4 & 93,67 & 91,58 & 0,456 & 0,709 \\
5 & 75,04 & 65,38 & 0,431 & 0,759 \\
\hline
\end{tabular}

Sumber : ${ }^{1}$ Suharsih dkk (1999); ${ }^{2}$ Panjaitan dkk (2015). 
Ke dua hasil penelitian sebelumnya sesuai dengan penelitian yang telah dilakukan oleh Sumirat dan Solehudin (2009). Berdasarkan penelitian pada 3 lokasi lahan (lahan terbuka, lahan sawah dan hutan sekunder di Kalimantan Selatan), Sumirat dan Solehudin (2009) mendapatkan koefisien korelasi (r) antara curah hujan dengan emisi $\mathrm{CH}_{4}$ adalah 0,33 . Hal ini menunjukkan semakin besar curah hujan, maka semakin tinggi fluks emisi $\mathrm{CH}_{4}$ sehingga emisi $\mathrm{CH}_{4}$ pada musim hujan lebih besar daripada di musim kemarau.

Emisi $\mathrm{CH}_{4}$ pada musim penghujan lebih tinggi daripada di musim kemarau pada lahan sawah disebabkan oleh enam faktor pendukung pembentukan $\mathrm{CH}_{4}$. Pertama pada musim hujan, lahan sawah memiliki volume genangan air yang lebih tinggi daripada di musim kemarau karena mendapat tambahan air berlebih dari air hujan. Ke dua, pada budidaya padi lahan sawah, di dasar permukaan lahan sawah terbentuk lapisan tapak bajak (hard pen) yang bersifat kedap air sehingga air hujan yang jatuh di lahan sawah tidak dapat berinfiltrasi dan akan semakin menaikkan ketinggian genangan air di dalam lahan sawah dengan sifat genangan air yang diam (statis). Semakin tinggi genangan air pada suatu badan air (termasuk lahan sawah), maka kondisi badan air akan semakin bersifat anaerob dan akan meningkatkan suhu air (Setyanto dan Suharsih, 2005). Pembentukan metana berbanding lurus dengan suhu. Semakin tinggi genangan air akan memicu peningkatan suhu air dan akan menstimulasi pembentukan emisi metana yang semakin besar (Treenberth, 1994). Ke tiga, air hujan selain menambah ketinggian genangan air pada lahan sawah juga memberikan material organik yang terbawa bersamaan aliran permukaan (run off) air hujan dan diendapkan di lahan sawah. Material organik ini berasal dari butiran tanah yang tererosi oleh air hujan. Material organik ini dapat menjadi substrat bakteri metanogen untuk menghasilkan $\mathrm{CH}_{4}$. Ke empat, curah hujan yang intensif pada saat musim hujan menguntungkan tanaman padi karena ketersediaan air menjadi cukup untuk pertumbuhan tanaman dan menghasilkan eksudat akar yang lebih banyak. Eksudat akar ini adalah substrat bagi bakteri metanogen dalam menghasilkan emisi $\mathrm{CH}_{4}$, semakin banyak eksudat akar yang dihasilkan akan mempertinggi emisi $\mathrm{CH}_{4}$ (Das dan Baruah, 2008). Ke lima, pembusukan material organik secara anaerob pada musim hujan lebih tinggi daripada di musim kemarau. Ke enam, bakteri adalah mikroorganisme yang bersifat ubikuotus yang berarti bahwa jumlah bakteri berlimpah dan dapat ditemukan di hampir semua tempat di dunia (darat, air, udara), termasuk juga bakteri metanogen sebagai penghasil metana biogenik (metana yang dihasilkan oleh organisme). Diperkirakan total jumlah bakteri yang mendiami muka bumi ini adalah $5 \times 10^{30}$ (Madigan dkk., 2009).

Air hujan selain memberikan dampak fisik pada lahan sawah (ketinggian genangan air dan suhu air), juga mengandung aspek kimia berupa kandungan $\mathrm{CO}_{2}$ terlarut dalam air hujan. Karbondioksida $\left(\mathrm{CO}_{2}\right)$ yang terdapat di atmosfer dapat tercuci dan terbawa ke permukaan tanah bersamaan air hujan yang jatuh. Karbondioksida $\left(\mathrm{CO}_{2}\right)$ yang terlarut dalam air hujan yang jatuh di lahan sawah dapat menjadi substrat bagi bakteri metanogen untuk menghasilkan metana $\left(\mathrm{CH}_{4}\right)$. Reaksi pembentukan $\mathrm{CH}_{4}$ dari $\mathrm{CO}_{2}$ disajikan pada persamaan 2.

$\mathrm{CO}_{2}+8 \mathrm{H}^{+}+$bakteri matanogen $\rightarrow \mathrm{CH}_{4}+2 \mathrm{H}_{2} \mathrm{O}+$ Energi

Berdasarkan analisis dari beberapa penelitian yang dilakukan, semuanya menunjukkan bahwa pada musim hujan emisi $\mathrm{CH}_{4}$ dari pertanian padi sawah lebih besar daripada di musim kemarau. Hal ini tidak berarti musim tanam padi harus dilakukan pada musim kemarau untuk meminimkan emisi $\mathrm{CH}_{4}$. Pada musim kemarau memang emisi $\mathrm{CH}_{4}$ lebih kecil daripada di musim hujan, tetapi pertanyaan selanjutnya adalah apakah kebutuhan air tanaman padi pada musim kemarau dapat terpenuhi jika saja mengandalkan dari air hujan. Dengan demikian untuk menentukan musim tanam padi yang optimum menghasilkan emisi $\mathrm{CH}_{4}$ dan kebutuhan air dapat terpenuhi harus dicek dengan pola curah hujan tahunan lokasi setempat yang akan ditanami.

Indonesia memiliki tiga tipe pola curah hujan, yaitu tipe monsunal, equatorial, dan lokal. Gambar 1 menyajikan tiga tipe pola curah hujan di Indonesia dan cakupan daerahnya.

Berdasarkan Gambar 1 dapat diketahui bahwa kawasan Indonesia menurut tipe pola curah hujan tahunan dapat dibagi menjadi 3 tipe pola curah hujan yaitu pola monsunal, equatorial, dan lokal. Pola curah hujan tipe monsunal memiliki musim basah (musim hujan) dari November-Februari dan musim kemarau dari Mei-Agustus. Lokasi dengan curah hujan tipe equatorial memiliki 2 periode musim hujan dalam setahun yaitu dari JanuariApril dan September-Desember dengan musim kemarau dari Mei-Agustus. Lokasi dengan curah hujan tipe lokal memiliki periode musim hujan yang lebih panjang dari April-Agustus dan memiliki 2 periode musim kemarau yaitu dari Januari-Maret dan September-Desember. Berdasarkan pertimbangan kebutuhan air tanaman dari curah hujan dan minimnya emisi $\mathrm{CH}_{4}$ yang 


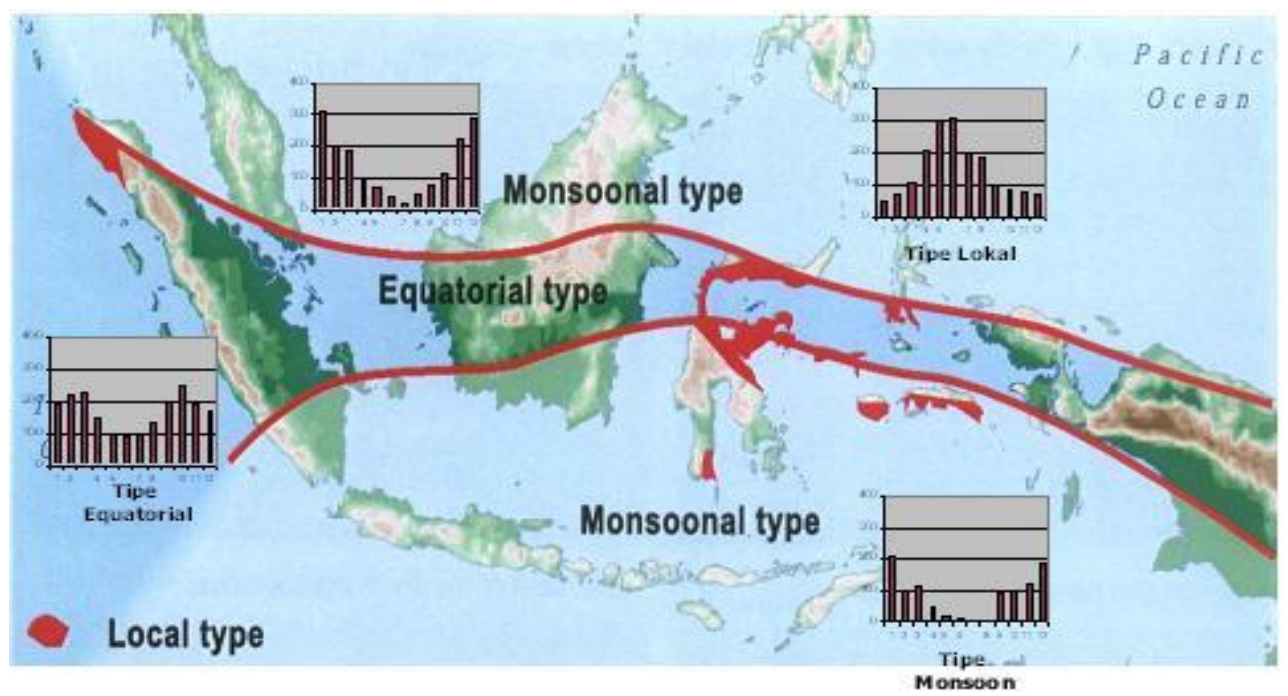

Gambar 1. Pola tipe curah hujan di Indonesia dan cakupan daerahnya (Sumber: Aldrian dan Susanto, 2003).

Tabel 3. Waktu musim tanam padi pada tipe curah hujan di Indonesia.

\begin{tabular}{cc}
\hline Tipe curah hujan & Emisi $\mathrm{CH}_{4}$ minim dan curah hujan \\
\hline Monsunal & Februari - Juni \\
Equatorial & April - Agustus \\
Lokal & Oktober - Maret \\
\hline
\end{tabular}

Sumber: Analisis peneliti.

Tabel 4. Rasio ekoefisiensi beberapa varietas padi.

\begin{tabular}{lc}
\hline \multicolumn{1}{c}{ Varietas padi } & Rasio ekoefisiensi $(\mathrm{g} / \mathrm{kg})$ \\
\hline Way apo buru & 20,8 \\
Dodokan & 22,4 \\
IR 36 & 22,8 \\
Mamberamo & 23,3 \\
IR 64 & 26,3 \\
Maros & 27,2 \\
Muncul & 27,6 \\
Cisadane & 34,0 \\
Tenggulang & 37,6 \\
Batang anai & 43,6 \\
Punggur & 44,9 \\
Banyuasin & 64,0 \\
Batang hari & 64,1 \\
\hline
\end{tabular}

Sumber: Analisis peneliti

dilepaskan, peneliti menyusun waktu musim tanam yang mempertimbangkan kriteria keduanya dan disajikan pada Tabel 3.

Berdasarkan Tabel 3 dapat diketahui bahwa dengan mempertimbangkan emisi $\mathrm{CH}_{4}$ yang minim dan kebutuhan air tanaman, maka musim tanam padi untuk lokasi dengan curah hujan tipe monsunal adalah Februari-Juni dan tipe equatorial antara April-Agustus. Lokasi dengan tipe curah hujan monsunal dan equatorial hanya dapat bertanam padi untuk 1 kali musim tanam dalam setahun. Lokasi dengan tipe curah hujan lokal dapat melakukan 2 kali musim tanam padi (musim tanam pertama Oktober-Desember dan musim tanam ke dua adalah Januari-Maret) dalam setahun dengan jenis varietas padi berumur pendek.

Lokasi dengan tipe curah hujan monsunal dapat melakukan awal musim tanam padi pada bulan Februari. Pada bulan Februari, walaupun masih termasuk dalam musim hujan, tetapi tanaman padi ketika baru ditanam belum mengemisikan $\mathrm{CH}_{4}$. Hal ini disebabkan emisi $\mathrm{CH}_{4}$ mulai dilepaskan ketika tanaman padi berusia 6 minggu atau 42 HST (hari setelah tanam) (Pschorn and Seiler, 1986). Kelebihan air pada awal musim tanam (Februari) dapat disimpan dalam waduk yang akan dapat dipergunakan pada saat musim tanam telah memasuki awal musim kemarau.

Lokasi dengan tipe curah hujan equatorial (Gambar 1) dapat mengawali musim tanam dari bulan April. Pada bulan ini, hujan mulai berkurang sehingga lahan sawah dan tanaman padi berpeluang tidak akan digenangi oleh air hujan. Lokasi dengan tipe curah hujan lokal dapat mengawali musim tanam pertama padi pada bulan Januari dan musim tanam ke dua di Oktober.

Setelah menentukan musim tanam yang minim emisi $\mathrm{CH}_{4}$, langkah selanjutnya adalah menentukan jenis varietas padi yang minim mengemisikan $\mathrm{CH}_{4}$ tetapi optimum pada produksi yaitu dengan analisis rasio ekoefisiensi. Tabel 4 menyajikan rasio ekoefisiensi beberapa varietas padi.

Berdasarkan Tabel 5 dapat diketahui jika memilih varietas padi Batanghari untuk ditanam dan tidak menanam varietas Way apo buru, maka lingkungan atmosfer akan mendapat tambahan emisi $\mathrm{CH}_{4}$ sebesar 43,3 g untuk setiap hektar lahan sawah dan setiap $\mathrm{kg}$ gabah yang dihasilkan relatif jika menanam varietas Way apo buru. Semakin memilih varietas padi pada urutan semakin akhir, maka risikonya adalah tambahan emisi $\mathrm{CH}_{4}$ ke lingkungan atmosfer akan semakin besar. Selain itu 
Tabel 5. Tambahan emisi $\mathrm{CH}_{4}$ terhadap varietas Way apo buru.

\begin{tabular}{lc}
\hline \multicolumn{1}{c}{ Varietas padi } & Tambahan emisi $\mathrm{CH}_{4}(\mathrm{~g} / \mathrm{kg})$ \\
\hline Dodokan & 1,6 \\
IR 36 & 2,0 \\
Mamberamo & 2,5 \\
IR 64 & 5,5 \\
Maros & 6,4 \\
Muncul & 6,8 \\
Cisadane & 13,2 \\
Tenggulang & 16,8 \\
Batang anai & 22,8 \\
Punggur & 24,1 \\
Banyuasin & 43,2 \\
Batang hari & 43,3 \\
\hline
\end{tabular}

Sumber: Analisis peneliti.

untuk mengurangi emisi $\mathrm{CH}_{4}$, kalaupun musim tanam dilakukan pada musim hujan dapat dilakukan dengan menanam jenis varietas padi yang memiliki emisi $\mathrm{CH}_{4}$ paling rendah.

Tahapan selanjutnya yang dapat dilakukan untuk mengurangi emisi $\mathrm{CH}_{4}$ setelah musim tanam dan varietas padi yang ditanam adalah teknik budidaya. Teknik budidaya padi lahan sawah dengan cara digenangi tujuan sebelumnya adalah untuk mengurangi pertumbuhan gulma (pesaing tanaman pokok), tetapi ternyata penggenangan lahan sawah yang ditanami padi menimbulkan masalah baru yaitu dihasilkannya emisi $\mathrm{CH}_{4}$ ke atmosfer dan timbulnya lapisan tapak bajak (hard pen) yang bersifat kedap air sehingga air hujan tidak dapat berinfiltrasi ke lapisan tanah yang lebih dalam. Air hujan atau irigasi yang tidak dapat berinfiltrasi pada lahan sawah akan menaikkan ketinggian genangan air dalam lahan sawah. Ketinggian genangan air dalam lahan sawah mengakibatkan kondisi lahan sawah lebih bersifat anaerob yang memicu terbentuknya $\mathrm{CH}_{4}$. Jika ketinggian genangan air dalam lahan sawah melebihi ketinggian pematang sawah, maka ketinggian genangan air berpotensi menimbulkan banjir untuk daerah sekitarnya. Dataran banjir yang terbentuk selama beberapa hari adalah juga sumber emisi $\mathrm{CH}_{4}$ ketika dataran banjir tersebut mengering.

Teknik budidaya padi lahan sawah memiliki ciri utama pada cara pemberian air yaitu dengan cara menggenangi lahan sawah. Penggenangan pada teknik budidaya lahan sawah memiliki dua dampak yang berlawanan, positif dan negatif. Dampak positif bahwa tanaman padi yang ditanam dalam kondisi tergenang pertama adalah keterbatasan kebutuhan air bukan menjadi faktor pembatas sehingga kebutuhan air terjamin. Ke dua adalah pengendalian gulma menjadi lebih mudah. Ke tiga adalah tersedianya unsur hara tertentu yaitu posfor (Sanchez, 1995).
Dampak negatif dari teknik budidaya padi dengan penggenangan selain terbentuknya lapisan kedap air juga dapat menurunkan daya hantar listrik yang memacu pencucian garam sehingga akan berakibat pada pencemaran tanah dan badan air. Pada tanah dengan kandungan pasir dan bahan organik yang tinggi, tetapi kadar besi rendah, penggenangan akan menghasilkan asam organik dan $\mathrm{H}_{2} \mathrm{~S}$ (asam sulfida) yang tinggi dan bersifat racun (toksik) pada tanaman.

Solusi dari lahan sawah yang berpotensi mengemisikan $\mathrm{CH}_{4}$ yang berasal karena teknik budidaya (penggenangan) adalah pertama dengan mengubah ketinggian genangan air pada lahan sawah menjadi tinggi genangan yang lebih pendek/lebih dangkal. Ke dua dengan mengubah cara pemberian air dan ke tiga dengan membuat genangan air dalam lahan sawah dari yang diam (penggenangan diam) menjadi bergerak (aerodinamis).

IPCC menyatakan bahwa salah satu faktor yang menentukan besarnya emisi $\mathrm{CH}_{4}$ (IPCC, 1994) adalah ketinggian genangan air dalam lahan sawah, semakin tinggi genangan air dalam lahan sawah, maka semakin besar emisi $\mathrm{CH}_{4}$ yang dihasilkan. Faktor ketinggian genangan air dalam lahan sawah juga tidak berpengaruh pada produksi padi, tetapi berpengaruh pada emisi $\mathrm{CH}_{4}$ yang dihasilkan. Catabay dalam International Rice Research Institute (IRRI, 1967) menyatakan bahwa penggenangan sedalam $5,10,15$, dan $20 \mathrm{~cm}$ tidak menunjukkan perbedaan produksi padi yang nyata. Menurut Chang dalam IRRI (1967) dinyatakan juga bahwa tinggi genangan sebesar $2,5 \mathrm{~cm}$ dari permukaan lahan sawah dapat menghasilkan produksi padi yang 5\% lebih tinggi daripada penggenangan dengan ketinggian $10 \mathrm{~cm}$. Arsyad (1989) menyatakan bahwa penggenangan lebih dari $10 \mathrm{~cm}$ malahan dapat mempertinggi sterilitas (kemandulan) beberapa varietas tanaman padi. Berdasarkan ke tiga penelitian tersebut dapat disimpulkan bahwa tinggi genangan air dalam lahan sawah dibuat jangan terlalu tinggi (dalam) cukup antara ukuran 2,5 sampai dengan $7,5 \mathrm{~cm}$. Ketinggian genangan air dalam lahan sawah yang tidak terlalu tinggi akan berdampak positif yaitu banyak areal sawah yang dapat diairi oleh air irigasi terutama pada musim tanam yang dilakukan di musim kemarau, selain itu emisi $\mathrm{CH}_{4}$ dapat dikurangi.

Selain mengubah ketinggian genangan air dalam lahan sawah untuk mengurangi emisi $\mathrm{CH}_{4}$ dari tahapan teknik budidaya, maka teknik ke dua adalah dengan mengubah cara pemberian air. Gambar 2 menyajikan emisi $\mathrm{CH}_{4}$ yang dihasilkan pada dua cara pemberian air yang berbeda. 


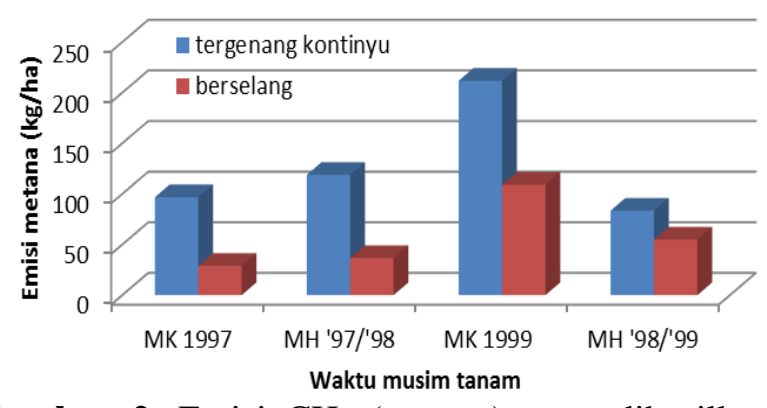

Gambar 2. Emisi $\mathrm{CH}_{4}$ (metana) yang dihasilkan pada dua teknik pemberian air. Keterangan: $\mathrm{MK}=$ musim kemarau, $\mathrm{MH}=$ musim hujan (Sumber: Suharsih dkk., 2000; Suharsih dkk (2001).

Berdasarkan Gambar 2 dapat diketahui bahwa pemberian air dengan cara menggenangi lahan sawah dengan terus-menerus (kontinyu) menghasilkan emisi $\mathrm{CH}_{4}$ yang lebih besar daripada pemberian air dengan cara berselang (tidak kontinyu), baik untuk musim tanam yang dilakukan pada musim hujan maupun musim kemarau. Hal ini disebabkan pada penggenangan kontinyu, air genangan bersifat diam/statis sehingga mengakibatkan kondisi lahan sawah semakin anaerob yang sesuai dan mendukung terbentuknya gas metana. Setyanto dan Suharsih (2005) menyatakan bahwa air tergenang adalah lingkungan yang cocok untuk pembentukan $\mathrm{CH}_{4}$ karena akan meningkatkan suhu tanah dan suhu air. Selanjutnya Cicerone, dkk. dalam Treenberth (1994) menyatakan bahwa pembentukan $\mathrm{CH}_{4}$ berbanding lurus dengan suhu media. Penggenangan air pada lahan sawah dengan teknik pemberian air secara berselang rata-rata menurunkan emisi $\mathrm{CH}_{4}$ pada musim kemarau sebesar 59,36\% dan pada musim hujan dengan teknik pemberian air yang sama akan menurunkan emisi $\mathrm{CH}_{4}$ sebesar 51,68\%.

Teknik budidaya lahan sawah ke tiga yang dapat mengurangi emisi $\mathrm{CH}_{4}$ adalah mengubah dari kondisi penggenangan air yang diam menjadi bersifat aerodinamis. Penggenangan diam akan meningkatkan kondisi anaerob lahan sawah yang berarti akan meningkatkan emisi $\mathrm{CH}_{4}$, tetapi penggenangan yang bersifat aerodinamis akan mengubah dari kondisi lahan sawah yang anaerob menjadi aerob. Teknik untuk mengubah dari kondisi lahan sawah yang anaerob menjadi aerob salah satunya adalah dengan memadukan pertanian padi sawah dengan tanaman paku air (spesies Azolla pinata dan atau Azolla microphyllia) dan pemeliharaan (budidaya) ikan jenis air tawar. Peneliti mengistilahkan teknik budidaya ini dengan sebutan mina padi plus. Hasil penelitian dari Sasa (2003) menyatakan bahwa teknik budidaya padi dengan perlakuan memadukannya dengan tanaman

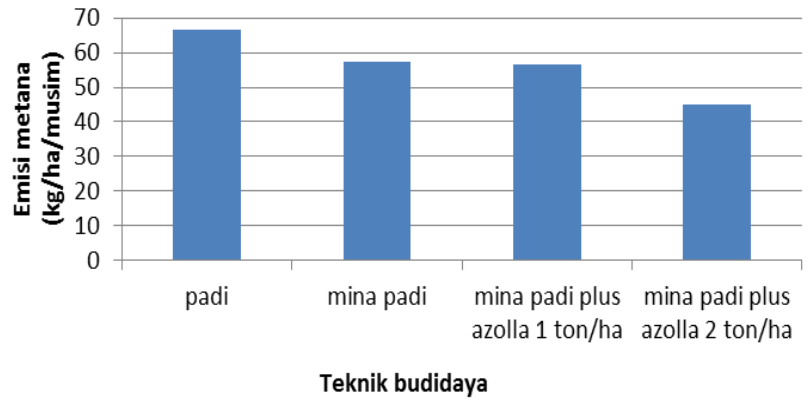

Gambar 3. Emisi $\mathrm{CH}_{4}$ yang dihasilkan dari beberapa teknik budidaya padi sawah (Sumber: Sasa, 2003).

paku air sebanyak 2 ton/ha dan memelihara ikan menghasilkan emisi $\mathrm{CH}_{4}$ yang paling kecil. Gambar 3 menyajikan emisi $\mathrm{CH}_{4}$ yang dihasilkan dari beberapa teknik budidaya padi sawah.

Berdasarkan Gambar 3 dapat diketahui bahwa teknik budidaya mina padi plus tanaman paku air sebanyak 2 ton/ha dapat mengurangi emisi $\mathrm{CH}_{4}$ sebesar $21,5 \mathrm{~kg} / \mathrm{ha} /$ musim tanam daripada tanpa menggunakan teknik budidaya mina padi plus (teknik budidaya padi saja). Hal ini dapat terjadi disebabkan dalam teknik budidaya mina padi plus, ikan dapat menjadikan tanaman paku air (Azolla sp) sebagai pakan sehingga ikan tumbuh dengan baik dan berkembang biak. Pergerakan ikan di dalam lahan sawah akan mengakibatkan $\mathrm{O}_{2}$ dari atmosfer berdifusi ke dalam air sehingga menjadi oksigen terlarut dalam air sawah dan aerasi dalam lahan sawah menjadi lebih baik. Semakin banyak ikan berkembang biak dalam lahan sawah, maka semakin tinggi aktivitas gerakannya dan semakin banyak oksigen atmosfer berdifusi ke dalam lahan sawah. Lahan sawah tergenang yang sebelumnya bersifat anaerob, dengan adanya pergerakan ikan akan menjadi aerob, sehingga emisi $\mathrm{CH}_{4}$ berkurang. Pada kondisi aerob, bakteri metanogen tidak dapat bekerja menghasilkan $\mathrm{CH}_{4}$ sehingga emisi $\mathrm{CH}_{4}$ berkurang. Emisi $\mathrm{CH}_{4}$ yang berkurang di permukaan akan mempengaruhi juga pengurangan konsentrasi $\mathrm{CH}_{4}$ di atmosfer. Metana biogenik yang dihasilkan di permukaan (salah satunya dari lahan sawah ditanami padi) berasal dari kondisi sumber media yang bersifat anaerob (tergenang).

Ikan dapat tumbuh berkembang baik karena adanya pakan ikan berupa tanaman paku air yang juga tumbuh subur karena bersimbiosis dengan ganggang spesies Anabaena azollae. Ganggang jenis ini dapat mengikat $\mathrm{N}_{2}$ bebas di atmosfer ke dalam air dan kalium. Tambahan pupuk untuk tanaman paku air adalah dari kotoran ikan sendiri. Tanaman padi sendiri mendapat tambahan pupuk dari ganggang jenis Cyanophiceae ini. 


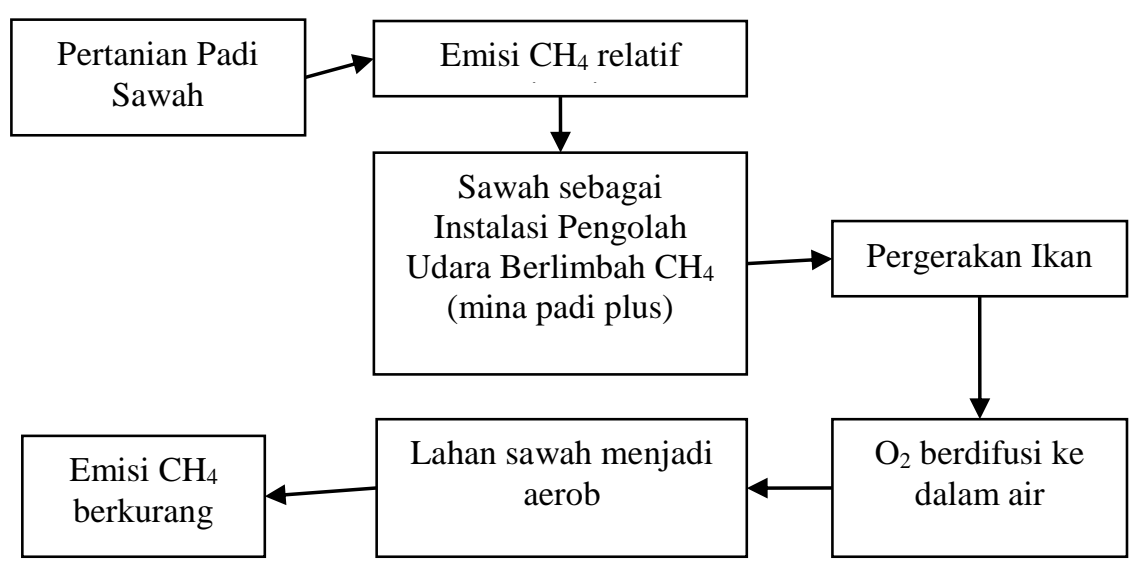

Gambar 4. Konsep instalasi terbuka pengolah udara berlimbah $\mathrm{CH}_{4}$ (Sumber: Analisis peneliti).

Lahan sawah dengan teknik budidaya mina padi plus dapat dijadikan sebagai instalasi terbuka pengolahan udara berlimbah $\mathrm{CH}_{4}$. Gambar 4 menyajikan konsep instalasi terbuka pengolahan udara berlimbah $\mathrm{CH}_{4}$.

Selain dengan teknik budidaya mina padi plus pada lahan sawah dapat juga dibiakkan bakteri metanotrof untuk mengurangi emisi $\mathrm{CH}_{4}$ ke atmosfer. Adanya bakteri metanotrof di dalam lahan sawah tanah dapat mengurangi emisi $\mathrm{CH}_{4} \mathrm{ke}$ atmosfer sebesar 20-60 Tg atau setara 4-10\% total emisi $\mathrm{CH}_{4}$ global (Roslev dkk., 1997)

Bakteri metanotrof tergolong jenis bakteri kemoautotrof yaitu bakteri yang dapat membuat makanannya sendiri dengan menggunakan energi kimia berupa gas $\mathrm{CH}_{4}$ (yang dihasilkan oleh bakteri metanogen) sebagai sumber makanannya. Sebelum gas $\mathrm{CH}_{4}$ diemisikan ke atmosfer, maka bakteri metanotrof ini mengoksidasi gas $\mathrm{CH}_{4}$. Spesies bakteri metanotrof yang telah teridentifikasi antara lain adalah Methylocystis parvus, Methylosinus sporium, Methylobacter agile, Methylobacter whittenburyi, Methylomonas methanica, Methylococcus capsulatus, dan Methanobacterium bryantii (Jaatinen dkk., 2004).

Kombinasi dari teknik budidaya padi lahan sawah dengan tanaman paku air, ikan air tawar, dan bakteri metanotrof akan dapat lebih besar mengurangi emisi $\mathrm{CH}_{4}$. Gas $\mathrm{CH}_{4}$ yang masih dapat dihasilkan dari budidaya padi dengan teknik mina padi plus dapat dioksidasi oleh bakteri metanotrof sehingga emisi $\mathrm{CH}_{4}$ yang dilepaskan ke atmosfer dapat lebih kecil lagi.

\section{KESIMPULAN}

Berdasarkan kajian ini maka dapat diketahui bahwa musim tanam padi yang dilakukan pada musim kemarau menghasilkan emisi $\mathrm{CH}_{4}$ yang lebih kecil daripada di musim hujan. Musim tanam padi yang dilakukan pada musim hujan menghasilkan emisi $\mathrm{CH}_{4}$ yang lebih tinggi antara $18,13 \%$ sampai dengan $47,1 \%$ tergantung pada $\mathrm{pH}$ air hujan, jenis varietas padi yang ditanam, jenis tanah, dan teknik budidaya yang digunakan. Musim tanam padi rendah emisi $\mathrm{CH}_{4}$ yang direkomendasikan untuk lokasi dengan tipe curah hujan monsunal adalah Februari - Juni, tipe curah hujan equatorial antara April sampai dengan Agustus, dan tipe curah hujan lokal Oktober Maret.

Menurut analisis rasio ekoefisiensi, maka varietas padi yang mendapat prioritas untuk ditanam terlebih dahulu karena menghasilkan emisi $\mathrm{CH}_{4}$ rendah tetapi produksi optimum adalah varietas padi berturut-turut Way apo buru, Dodokan, IR 36, Mamberamo, IR 64, Maros, Muncul, Cisadane, Tenggulang, Batang Anai, Punggur, Banyuasin, dan terakhir varietas padi Batanghari. Semakin memilih varietas padi pada urutan semakin akhir, maka risiko berupa tambahan emisi $\mathrm{CH}_{4}$ ke lingkungan atmosfer akan semakin besar.

Kombinasi antara musim tanam dengan jenis varietas padi dapat dilakukan dengan menanam jenis varietas padi paling rendah emisi $\mathrm{CH}_{4}$ pada musim hujan sehingga emisi $\mathrm{CH}_{4}$ pada musim hujan dapat dikurangi. Terdapat tiga cara untuk mengurangi emisi $\mathrm{CH}_{4}$ dari teknik budidaya padi lahan sawah. Pertama dengan mengubah ketinggian genangan air pada lahan sawah menjadi tinggi genangan yang lebih pendek. Ke dua dengan mengubah cara pemberian air dan ke tiga dengan membuat genangan air dalam lahan sawah dari yang diam (penggenangan diam) menjadi bergerak (aerodinamis).

Teknik budidaya padi lahan sawah dengan cara pemberian air berselang rata-rata menurunkan emisi $\mathrm{CH}_{4}$ pada musim kemarau sebesar $59,36 \%$ dan pada musim hujan dengan teknik pemberian air yang sama akan menurunkan emisi $\mathrm{CH}_{4}$ sebesar 
$51,68 \%$ jika dibandingkan dengan pemberian air secara terus-menerus (kontinyu).

Selain itu teknik budidaya padi lahan sawah dengan memadukan membiakkan tanaman paku air sebanyak 2 ton/ha dan pemeliharaan ikan air tawar dapat mengurangi emisi $\mathrm{CH}_{4}$ sebesar 21,5 $\mathrm{kg} / \mathrm{ha} /$ musim tanam. Pada lahan sawah juga dapat ditumbuhkan bakteri metanotrof yang dapat mengurangi emisi $\mathrm{CH}_{4}$ ke atmosfer sebesar 20-60 $\mathrm{Tg}$ atau setara $4-10 \%$ dari total emisi $\mathrm{CH}_{4}$ global.

\section{UCAPAN TERIMAKASIH}

Terima kasih penulis ucapkan kepada Balai Penelitian Lingkungan Pertanian, Pusat Penelitian dan Pengembangan Tanaman Pangan, Kementerian Pertanian atas data dan pelayanan yang diberikan sehingga mendukung kajian ini.

\section{DAFTAR PUSTAKA}

Aldrian, E dan Susanto, R.D., 2003. Identification of Three Dominant Rainfall Regions within Indonesia and Their Relationship to Sea Surface Temperature. International Journal of Climatology, 23:1435-1452.

Arsyad, S., 1989, Konservasi Tanah dan Air, IPB Press, Bogor.

Biswas, A. K., dan Biswas, M. R., 1979. "The Ozone Layer" in Proceeding of The Meeting of Experts Designated by Governments, Intergovernmental and Non Governmental Organizations on The Ozone Layer, Pergamon Press, Washington DC.

BPS, 2014. Neraca Bahan Pangan 2014, Badan Pusat Statistik, Jakarta.

Das, K., dan Baruah, K.K., 2008, A Comparison of Growth and Photosynthetic Characteristics of Two Improved Rice Cultivars on Methane Emission from Rainfed Agroecosystem of Northeast India. Agricultural Ecosystem Environment. 124:105-113.

DNPI, 2010, Kurva Biaya (Cost Curve) Pengurangan Gas Rumah Kaca di Indonesia. Dewan Nasional Perubahan Iklim Jakarta.

IPCC, 1994, Greenhouse Gas Inventory Workbook, Volume 2, US EPA. Intergovernmental Panel on Climate Change Cambridge.

IPCC, 1995, Climate Change 1994. Eds. J. T. Houghton, L. Meira Filho, J. Bruce, H. Lee, B. Callander, E. Haites, N. Harris and K. Maskell. 399 pp. Cambridge University Press, Intergovernmental Panel on Climate Change Cambridge.

IRRI. 1967. Rice Production Manual. International Rice Research Institute Los Banos.
Jaatinen, K., Knief, C., Dunfield, P. F., Yfjala, K., dan Fritze, H., 2004, Methanotrophic Bacteria in Boreal Forest Soil After Fire, FEMS Microbiol. Ecol. 50(3):195-202.

Karim, K, 1985, Analisa Curah Hujan dan Penggunaannya untuk Menyusun Pola Tanam Tanaman Pangan di Beberapa Lahan Tadah Hujan di Provinsi Daerah Istimewa Aceh, Fakultas Pasca Sarjana, IPB, Bogor.

Kiehl, J.T., dan Dickinson, R.E., 1987. A Study of Radiative Effects of Enhanced Atmospheric $\mathrm{CO}_{2}$ and $\mathrm{CH}_{4}$ on Early Earth Surface Temperatures. Journal Geophysics. Res. 92:2991-2998.

Lelieveld, J., dan Crutzen, P.J., 1993. Methane Emission into The Atmosphere, An Overview. p. 17-25 in van Amstel, A.R. (Ed.). Methane and Nitrous Oxide, Methods in National Emission Inventories and Option for Control. Proceeding International IPCC Workshop. Amsterdam.3-5 February 1993.

Madigan, M.T., Martinko, J., Dunlap, P.V., dan Clark, D.P., 2009. Brock Biology of Microorganisms, 12th Ed. Upper Saddle River, New Jersey.

Mosier, A.R., Bronso, K. F., Freny, J.R., dan Keerthsinghe, D.G., 1994. Use in Nitrification Inhibitors to Reduce Nitrous Oxide Emission from Urea Fertilized Soils. In $\mathrm{CH}_{4}$ and $\mathrm{N}_{2} \mathrm{O}$; Global Emission and Controls from Rice Fields and Other Agricultural and Industrial Sources. NIAES. p. 122-124.

Panjaitan, E., Indradewa, D., Martono, E., dan Sartohadi, J., 2015, Sebuah Dilema Pertanian Organik Terkait Emisi Metan, Jurnal Manusia dan Lingkungan; 22(1):66-72.

Pschorn, A. H., dan Seiler, W., 1986, Methane Emission During Cultivation Period from An Italian Rice Paddy. Journal of Geophysical Research: Atmosphere, 91: 11803-11814.

Rahmansyah, M., dan Sudiana, I.M., 2010, Soil Microbial Enzymatic Activity Relate to Role Of methanotrophic Bacteria in The Tropical Forest Soil of Gunung Salak National Park, ARPN Journal of Agricultural and Research, 5(2):51-57.

Roslev, P., Iversen, N., and Henriksen, K., 1997, Oxidation and Assimilation of Atmospheric Methane by Soil Methane Oxidizers. Journal of Applied and Environemnatl Microbiology 63:874-880.

Sasa, J. J, 2003, Azolla (Azolla microphylla) dan Emisi Gas Metan Pada Sistem Minapadi di Lahan Sawah Irigasi, Prosiding Seminar Nasional Pengelolaan Lingkungan Pertanian, Surakarta, 21 Oktober 2003, Fakultas 
Pertanian Universitas Negeri Sebelas Maret, Surakarta.

Sanchez, P. A, 1995, Sifat dan Pengelolaan Tanah Tropika, ITB Press, Bandung.

Schmidheiny, S, 1992, A Global Business Perspective on Development and The Environment. Cambridge, Mass: The MIT Press

Setyanto, P., dan Suharsih, 2005, Mitigasi Gas Metan dari Lahan Sawah, Laporan Tahunan Lokal Penelitian Tanaman Pangan, Jakenan, Pati. Balai Penelitian Lingkungan Pertanian, Kementerian Pertanian. Jakarta.

Suharsih, P. Setyanto, A.K. Makarim, 1999, Emisi Gas Metan dari Lahan Sawah Akibat Pengaturan Air Tanaman Padi, dalam Risalah Seminar Hasil Penelitian Emisi Gas Rumah Kaca dan Peningkatan Produktivitas Padi di Lahan Sawah, Bogor, 24 April 1999, Puslitbang Tanaman Pangan, Balitbang Pertanian, Bogor.

Suharsih, P. Setyanto, A.K. Makarim, 2000, Pengaruh Pengelolaan Air Terhadap Emisi Gas
$\mathrm{CH}_{4}$ Pada Lahan Sawah di Jakenan, Jawa Tengah, dalam Proseding Seminar Nasional Budi Daya Tanaman Pangan Berwawasan Lingkungan, Jakenan, 7 Maret 2000, Puslitbang Tanaman Pangan, Balitbang Pertanian, Bogor.

Susilawati, H.L, Setyanto, P., Kartikawati, R., 2009, Karakteristik Tanaman Padi Pasang Surut dan Perbedaannya Terhadap Fluks $\mathrm{CH}_{4}$ di Tanah Gambut, Jurnal Tanah dan Iklim, 30:67-79.

Sumirat, U., dan Solehudin A., 2009. Nitrous Oksida $\left(\mathrm{N}_{2} \mathrm{O}\right)$ dan Metana $\left(\mathrm{CH}_{4}\right)$ Sebagai Gas Rumah Kaca, TORSI 7(2):13-20.

Treenberth, K, 1994, Climate System Modelling, Academy Press, New York.

Warneck, 1988, in Climate Science of Methane, Chapter II, www.ourenergypolicy.org/wpcontent/upload/2013/10/chapter02.pdf.

Yagi, K., dan Minami, K., 1990. Effect of Organic matter Application of Methane Emission from Some Japanese Paddy Fields. Soil Science Plant Nutrition. 36:599-610. 